\title{
1,1'-Biazulene derivatives. Syntheses and reactions
}

\section{Alexandru C. Razus, ${ }^{*}$ Liviu Birzan, Stefania Nae, Carmen Nitu, Victorita Tecuceanu, and Valentin Cimpeanu}

\author{
Institute of Organic Chemistry “C. D. Nenitzescu” of Romanian Academy, Spl. \\ Independentei 202B, PO Box 15-258, 71141-Bucharest, ROMANIA \\ E-mail: acrazus@cco.ro.
}

(received 16 Jul 2001; accepted 21 Aug 2002; published on the web 29 Aug 2002)

\begin{abstract}
3,3'-Disubstituted 1,1'-biazulene derivatives were obtained in good yields starting from thedimers* of azulene-1-azo aromatic compounds and from the corresponding Schiff bases coupled at 3 positions.
\end{abstract}

Keywords: Biazulene synthesis, Schiff's bases

\section{Introduction}

Several different synthetic approaches to the compounds with the general formulae 1a-c have been developed over the last fifty years. ${ }^{1}$ However, the compounds attracted interest when it was found that some of them possess valuable non-linear optical properties. ${ }^{2}$ Therefore, we have decided to develop more effective methods for the synthesis of these compounds and to study their structure and chemical properties. We have already reported the results for the compounds 1a and 1b. ${ }^{3,4}$

$$
\begin{array}{ll}
\text { Az-A=B-Ar } & A z=\text { substituted or unsubstituted 1-azulenyl } \\
\text { 1a-c } & A r=\begin{array}{l}
\text { substituted or unsubstituted aryl, } \\
\text { heteroaryl or 1-azulenyl }
\end{array} \\
\text { a: } A=B=N & \\
\text { b: } A=C H ; B=N & \\
\text { c: } A=B=C H &
\end{array}
$$

* The terms dimerization and dimer are used for coupling with the elimination of two hydrogen atoms and for the products resulted in these reactions, respectively. 
One of the most interesting reactions of $\mathbf{1}$ consists in the single electron oxidation. It is well known that the low oxidation potential of the azulenes ${ }^{5}$ make them highly susceptible to oxidation which proceeds unselecively and in low yields. ${ }^{6,7}$ In contrast, Azulenes substituted with a double bond at $\mathrm{C} 1$ as in compound $\mathbf{1}$ display increased oxidation potential which allows for chemical ${ }^{3 b, c, e}$ and electrochemical oxidation ${ }^{3 \mathrm{~d}}$ without damage of the azulene skeleton. The dimers coupled at $\mathrm{C} 1$ were obtained as the main oxidation products. The almost complete conversion of the starting materials and the good yield of the dimers obtained inspired us to use this reaction for the syntheses of the interesting 1,1'-biazulenes which until now have been obtained by Ullmann type coupling. As the starting coupling reagent, Morita and Takase ${ }^{8}$ have used ethyl 1-iodo-3-azulene carboxylate. In spite of the high coupling yield, the utility of the procedure for the syntheses of 1,1'-biazulene and their derivatives seems to be limited because of the difficult accessibile starting materials and by the fact that the carboxylate group offers rather few possibilities for subsequent transformations.

In the present paper, two types of starting materials were considered for 1,1'-biazulene synthesis, namely bis azo derivatives $\mathbf{3}$ and bis Schiff bases, 5 (Scheme 1 and, Scheme 2, respectively). The compounds $\mathbf{3}$ and $\mathbf{5}$ were obtained by oxidation of the corresponding monomers $\mathbf{2}^{3 \mathrm{~b}}$ and $\mathbf{4}^{3 \mathrm{e}}$ with anhydrous $\mathrm{FeCl}_{3}$ in benzene. The influence of the substituent $\mathrm{R}$ on the oxidation in both cases was discussed ${ }^{3 b 3 e}$ and $\mathrm{OCH}_{3}$ was found to be most favorable for dimer generation.

\section{Results and Discussion}

\section{Reaction of azo-dimer}

The reduction of 3,3'-bis-azo compound 3a with zinc/acetic acid generated 3,3'-diamino-1,1'biazulene, $\mathbf{6}$ and anisidine $\mathbf{7}(\mathrm{X}=\mathrm{H})$. Unfortunately, the compound $\mathbf{6}$ was quite unstable and only ${ }^{1} \mathrm{H}$ - and ${ }^{13} \mathrm{C}$-NMR spectra could be recorded for this product in the mixture with $\mathbf{7}(\mathrm{X}=\mathrm{H})$. However, the compound $\mathbf{6}$ could be quenched with methyl chloroformate to give the corresponding bis-methoxycarbamide 8 which was separated from the methoxycarbamide $\mathbf{7}$ ( $\mathrm{X}=$ $\mathrm{CO}_{2} \mathrm{CH}_{3}$ ) and completely characterized.

When the reduction medium ( $\mathrm{Zn}$ and acetic acid) acetic anhydride or benzoyl chloride was added, acylated bis-amines 9a and $\mathbf{9 b}$ were obtained together with acylated para-anisidine, 7 (X $=\mathrm{CH}_{3} \mathrm{CO}$ or $\mathrm{C}_{6} \mathrm{H}_{5} \mathrm{CO}$ ). The products were separated by column chromatography adding triethylamine to the eluent in order to avoid the destruction of the amides.

Our attempts to obtain bis-hydrazo compounds by reduction with hydrazine hydrate/ $\mathrm{Ni}$ Raney failed and after treatment with methyl chloroformate only bis-methoxycarbamide 8 and $\mathbf{7}$ ( $\mathrm{X}=\mathrm{CO}_{2} \mathrm{CH}_{3}$ ) could be detected in low yields in the reaction mixture. 


\section{Reactions of Schiff base dimer}

By the chemical oxidation $\left(\mathrm{FeCl}_{3}\right)$ of 1-azulene carbaldehyde only 3-chlorinated product was obtained (33\% yield) instead of the dialdehyde 11. However, the generation of 11, in $100 \%$ yield, was realized by the hydrolysis of Schiff base dimers, 5 (Scheme 2). It is interesting that although the hydrolysis of Schiff base monomers, 4, occurs fast, the corresponding dimers 5 react only slowly and in the presence of copper acetate as catalyst. A possible explanation for the observed difference is the low solubility of these dimers in the reaction medium. This convenient way
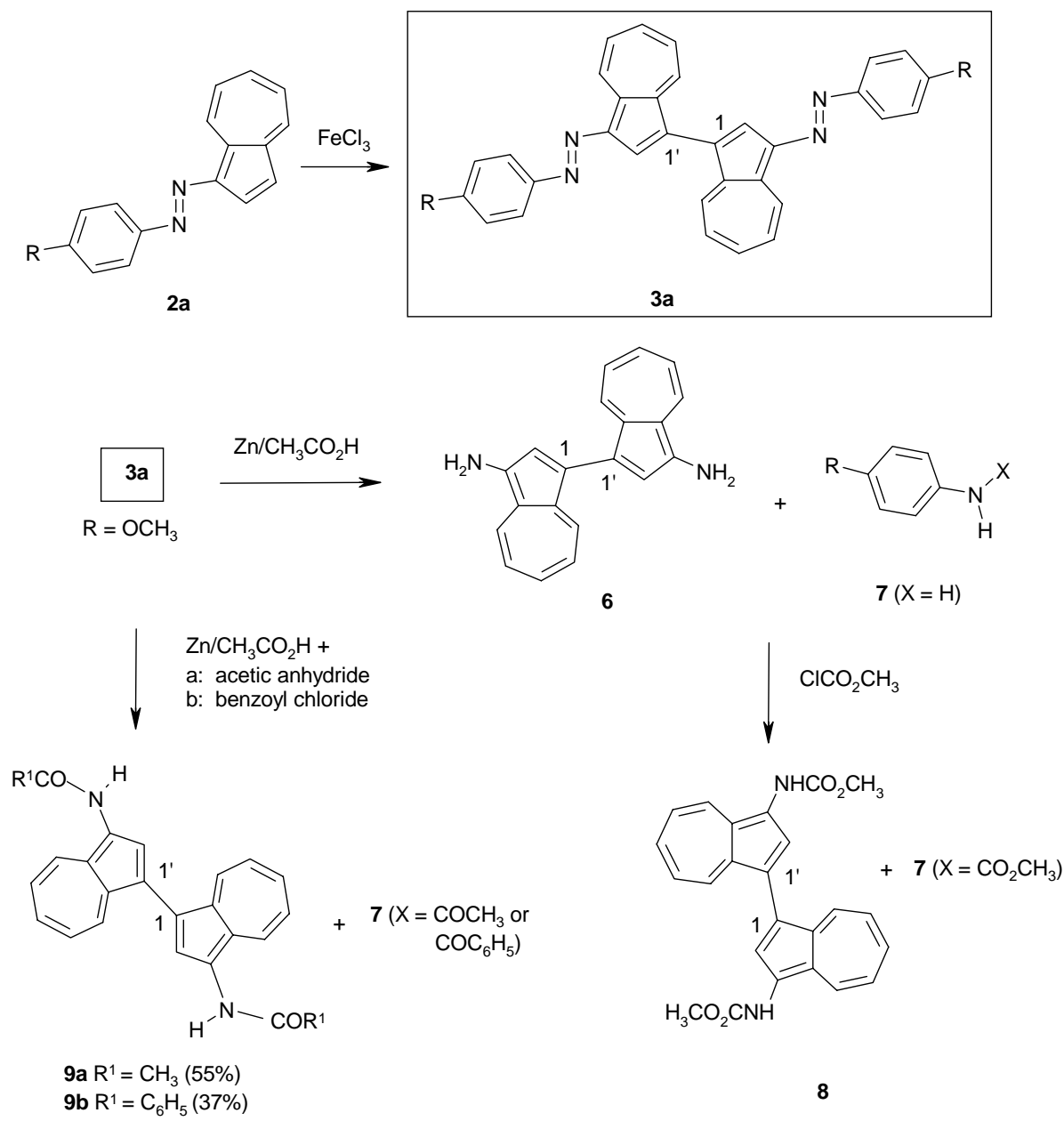

SCHEME 1

to access the dialdehyde $\mathbf{1 1}$ was important because the CHO group may be transformed to other functional groups. Thus, the diol 12 was generated by the reduction of $\mathbf{1 1}$ with $\mathrm{NaBH}_{4}$ in methanol and the dicarboxylic acid $\mathbf{1 4}$ was formed by the oxidation with potassium permanganate in pyridine. Exhaustive reduction of $\mathbf{1 1}$ with $\mathrm{NaBH}_{4}$ in the presence of $\mathrm{BF}_{3} \cdot\left(\mathrm{C}_{2} \mathrm{H}_{5}\right)_{2} \mathrm{O}$ gave rise to $3,3^{\prime}$-dimethyl-1,1'-biazulene 13. The reaction time for all these transformations was longer for the dimer thane for the monomer, maybe due to the low solubility 
of the dialdehyde 11. The study of Wittig reaction of $\mathbf{1 1}$ is in progress. This reaction could represent the starting point for the syntheses of interesting large molecules containing azulene moieties and double bonds.

One of the useful reactions of the CHO group is its replacement with hydrogen. The reported yields ${ }^{9}$ for the decarbonylation of azulenic aldehydes in the presence of pyrrole under mild conditions were between 36 and 60\%. By decarbonylation of dialdehyde 11 we obtained 1,1'Biazulene 10 in only 10-20\% yields. However starting from the dimer Schiff base 5a the yield was above $40 \%$. The reaction sequence: azulene $\rightarrow$ 1-azulenecarbaldehyde $\rightarrow$ corresponding Schiff base $\rightarrow$ dimerization $\rightarrow$ reaction with pyrrole that occurs in a very good over-all yield, represents an excellent way for the generation of hydrocarbon $\mathbf{1 0}$ starting from azulene.
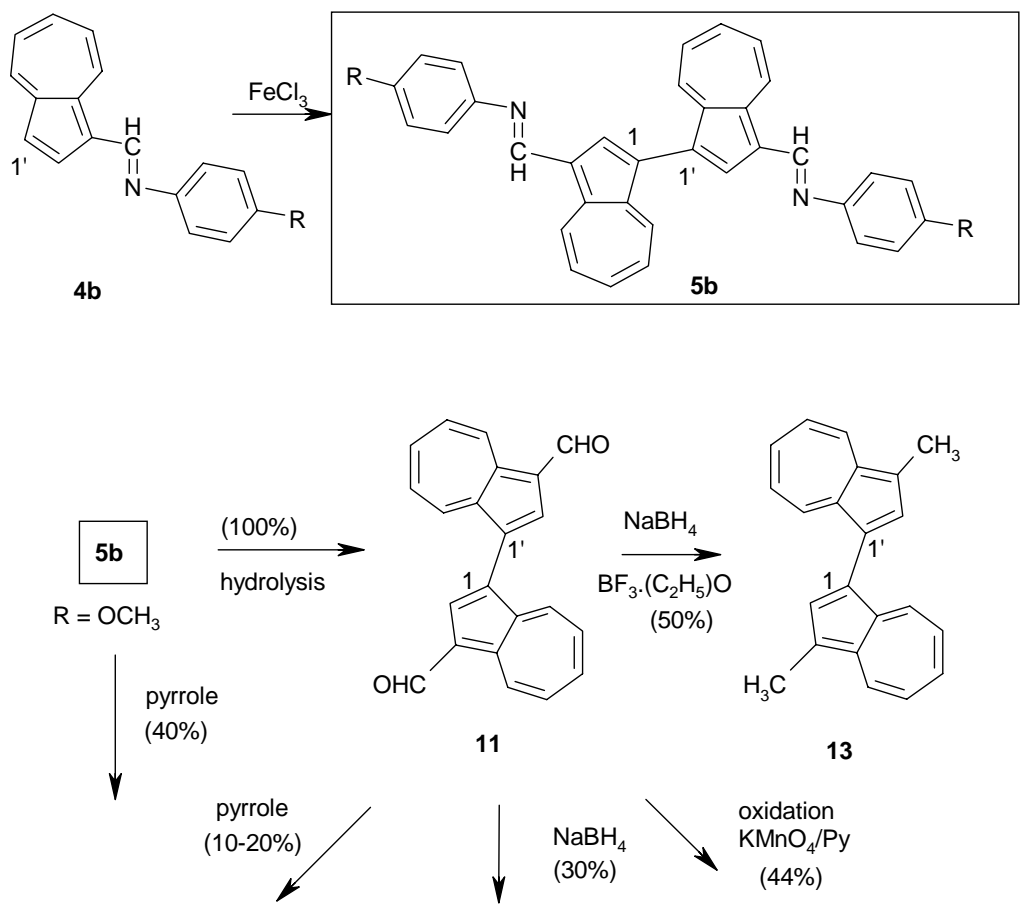

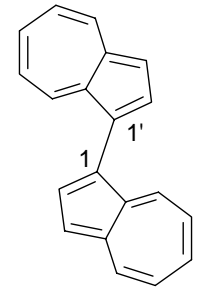

10

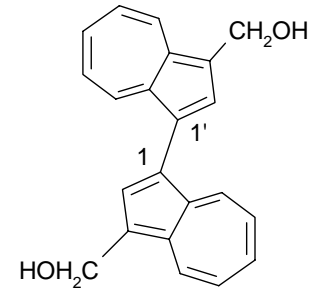

12

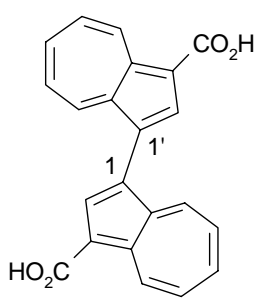

14

SCHEME 2

The convenient access to $\mathbf{1 0}$ triggered a study of some reactions of this interesting hydrocarbon (Scheme 3). We have only studied reactions with electrophiles, which occur in 
positions 3 and 3', some of which are reported below. Further investigations of reactions with nucleophiles or of redox and radical reactions are in progress.

Friedel Crafts acylation occurred in good yield in the presence of $\mathrm{SnCl}_{4}$ as for the unsubstituted azulene. ${ }^{10}$ Reaction with acetyl chloride produced the diacetylated product $15 \mathrm{R}=$ $\mathrm{CH}_{3}$ in $58 \%$ yield.

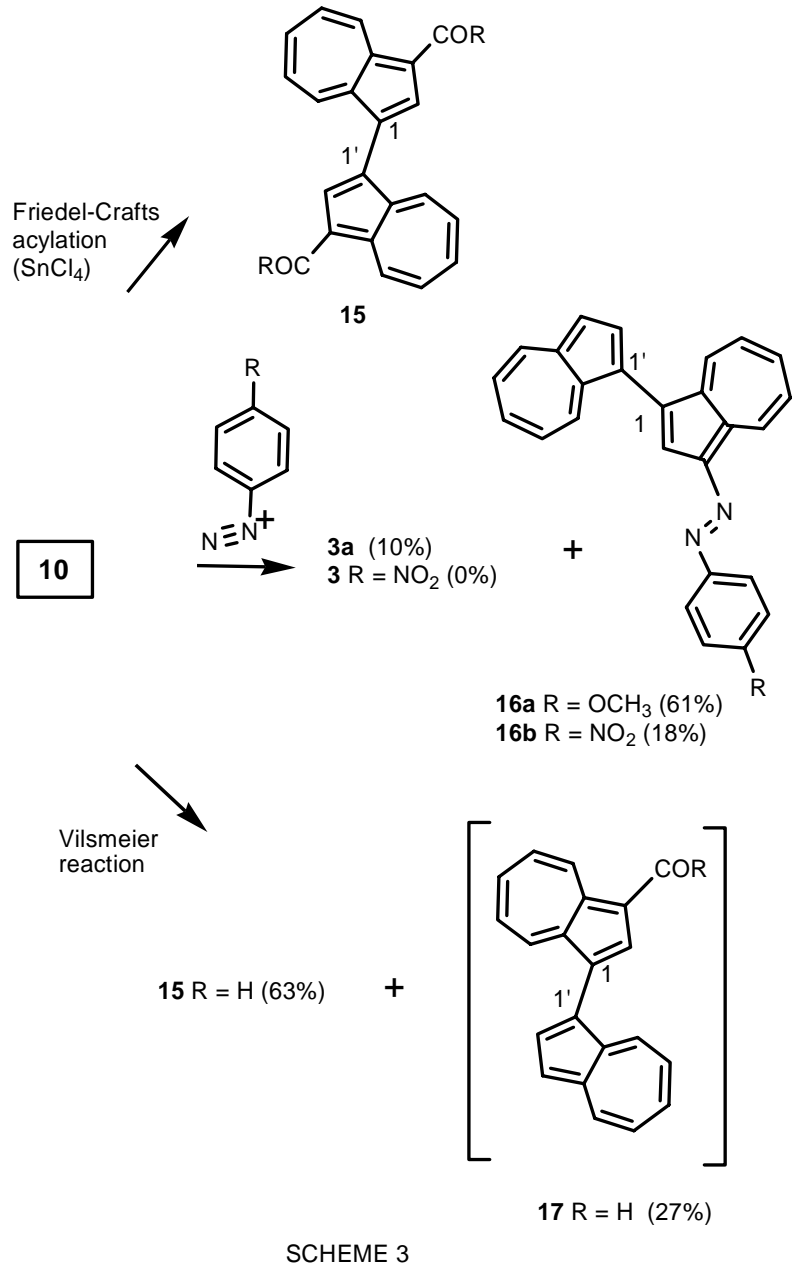

Vilsmeier acylation of $\mathbf{1 0}$ using the same protocol as for azulene ${ }^{11}$ with equimolar amounts of dimethylformamide or dimethylacetamide gave the 3-substituted compound 17. With excess of formylating agent the 3,3'-disubstituted compound 15 was formed, The coupling reaction with diazonium salts reported in a previous paper deals with the oxidation of azulene-1azoaromatics. ${ }^{3 \mathrm{~b}}$ Also in this reaction for $\mathrm{R}=\mathrm{OCH}_{3} \mathbf{1 6 a}$ and 3a were generated, the major productbeing 16a. It is noteworthy that the same reaction with the diazonium salt derived from 4nitroaniline produced only monosubstituted product $\mathbf{1 6 b}$ was formed.

In conclusion, we have showed that the relatively easy procedure for the dimerization of azocompounds $1 \mathbf{a}^{3 \mathrm{a}, \mathrm{b}}$ and their corresponding Schiff bases $1 \mathbf{b}^{2 \mathrm{~d}}$ represents a very good starting 
point for the synthesis of many 1,1'-biazulene derivatives compounds otherwise difficult accessible.

\section{Experimental Section}

General Procedures. Melting points: Kofler apparatus (Reichert Austria). Elemental analyses: Perkin Elmer CHN 240B. UV spectra: Beckman DK-2A, UV 5240. IR: Beckmann IR 5A. Mass spectra: Finnigan MAT 311-A/100MS. ${ }^{1} \mathrm{H}-$ and ${ }^{13} \mathrm{C}-\mathrm{NMR}$ spectra: Bruker Avance DRX4 $\left({ }^{1} \mathrm{H}\right.$ : $\left.400 \mathrm{MHz},{ }^{13} \mathrm{C}: 100 \mathrm{MHz}\right)$ and Gemini $300\left({ }^{1} \mathrm{H}: 300 \mathrm{MHz},{ }^{13} \mathrm{C}: 75 \mathrm{MHz}\right)$, TMS was used as internal standard; when necessary, unequivocal signal assignment was confirmed by the analysis of the corresponding COSY and HETCOR spectra (the numbering for the exemplified compounds was indicated in Schemes and is not always correlated with the IUPAC nomenclature; when symmetrical products are described only one number in molecule is specified for both identical positions). Mass spectra: Finnigan MAT 311-A/100 MS and Carlo Erba QMD 1000. Column chromatography: basic alumina (activity BII-III (Brockmann)) or silica [70-230 mesh (ASTM)]. The dichloromethane (DCM) was distilled over calcium hydride.

\section{Biazulene derivatives from the azo dimer 3a}

3,3'-Diamino-1,1'-biazulene (6). To a vigorouslystirred solution of the dimer 3a (52 $\mathrm{mg}$, $0.1 \mathrm{mmol})$ in acetic acid $(3 \mathrm{~mL})$ at room temperature and under inert atmosphere, a large excess of powdered zinc ( $350 \mathrm{mg}$ ) was added in small portions in $15 \mathrm{~min}$. The reduction was monitored by thin layer chromatography (TLC) and if necessary an additional amount of zinc was added. The mixture was stirred for $1 \mathrm{~h}$ when the color of the solution changed from brown to green. DCM $(10 \mathrm{~mL})$ was added to the suspension, the separated organic layer was carefully washed with $20 \%$ aqueous sodium carbonate to neutralize the acetic acid, it was dried $\left(\mathrm{Na}_{2} \mathrm{SO}_{4}\right)$ and filtered. The green DCM solution was used either for the amines separation or for the synthesis of bis-methoxycarbamide, $\mathbf{8}$. After evaporation of the solvent in vacuum (with protection against air) gave the diamine 6 in a mixture with para-anisidine, $7 \mathrm{X}=\mathrm{H}$. The amine 6 decomposes rapidly. NMR Data for 6: ${ }^{1} \mathrm{H}-\mathrm{NMR}\left(\mathrm{CDCl}_{3}\right): \delta 6.53(\mathrm{t}, J=9.6 \mathrm{~Hz}, 2 \mathrm{H}, \mathrm{H}-5), 6.55(\mathrm{t}, J=9.6 \mathrm{~Hz}$, 2 H, H-7), 7.18 (t, $J=9.6$ Hz, 2 H, H-6), 7.25 (s, 4 H, NH), 7.50 (s, 2 H, H-2), 7.75 (d, $J=9.6$ Hz, $2 \mathrm{H}, \mathrm{H}-4), 7.90$ (d, $J=9.6 \mathrm{~Hz}, 2 \mathrm{H}, \mathrm{H}-8) ;{ }^{13} \mathrm{C}-\mathrm{NMR}\left(\mathrm{CDCl}_{3}\right)$ : $\delta 117.7$ (C-5), 120.1 (C-7), 123.2 (q), 123.5 (q), 125.8 (C-2), 131.8 (C-8), 133.7 (q), 134.6 (q), 136.0 (C-8), 138.8 (C-6).

3,3'-Bis(acetylamino)-1,1'-biazulene (9a). Dimer 3a (52 mg, $0.1 \mathrm{mmol}$ ) and potassium acetate $(0.1 \mathrm{~g})$ were dissolved in a mixture of acetic anhydride $(3 \mathrm{~mL})$ and acetic acid $(3 \mathrm{~mL})$. To the strongly stirred solution at room temperature and under inert atmosphere a large excess of powdered zinc (350 mg) was added in small portions during $15 \mathrm{~min}$; the reduction was monitored by TLC (when necessary a supplementary amount of zinc must be added). The mixture was stirred for one additional hour when the color of the solution changed from brown to green. To the reaction mixture DCM $(25 \mathrm{~mL})$ was added and the obtained solution was washed 
with water $(25 \mathrm{~mL})$, aqueous ammonia $(10 \%, 2 \times 25 \mathrm{~mL})$ and water $(25 \mathrm{~mL})$. The organic layer was dried $\left(\mathrm{Na}_{2} \mathrm{SO}_{4}\right)$, filtered and the solvent was vaporized. The residue was chromatographed on alumina, eluent DCM:triethylamine, 9:1 and the first colored fraction was collected. After solvent vaporization, the residue was washed several times with ethyl ether in small portions. The amount of the product $8 \mathrm{a}$ was $20 \mathrm{mg}$ ( $55 \%$ yield). Green crystals, m. p. $247^{\circ} \mathrm{C}$, (ether), IR (KBr): $v_{\max } 765(\mathrm{~m}), 1135$ (m), 1330 (m), 1370 (m), 1400 (sh), 1440 (m), 1520 (m), 1560 (s), 1590 (m), 1645 (s), 2390 (m), 3045 (m), 3200-3300 cm-1; UV (MeOH): $\lambda_{\max }$ [nm] (log ع): 210 (4.26), 227 (4.41), 250 (4.46), 278 (4.54), 298 sh (4.49), 309 sh (4.44), 316 sh (4.40), 398 (4.06), 610 (2.66), 668 (2.68); ${ }^{1} \mathrm{H}$ NMR (DMSO-d 6 ): $\delta 2.23$ (s, $6 \mathrm{H}, \mathrm{CH}_{3}$ ), 6.97 (t, $J=9.6 \mathrm{~Hz}, 2 \mathrm{H}, \mathrm{H}-5$ ), 7.02 (t, $J=9.6 \mathrm{~Hz}, 2 \mathrm{H}, \mathrm{H}-7$ ), 7.56 (t, $J=9.6 \mathrm{~Hz}, 2 \mathrm{H}, \mathrm{H}-6$ ), 8.14 (d, $J=9.6 \mathrm{~Hz}, 2 \mathrm{H}, \mathrm{H}-4$ ), 8.30 (d, $J=9.6,2 \mathrm{H}, \mathrm{H}-8$ ), 8.47 (s, $2 \mathrm{H}, \mathrm{H}-2$ ), 10.27 (s, $2 \mathrm{H}, \mathrm{NH}$ ); ${ }^{13} \mathrm{C}$ NMR (DMSO-d 6 ) $\delta: 23.48$ $\left(\mathrm{CH}_{3}\right), 120.9$ (C-5), 122.3 (C-7), 122.8 (q), 126.2 (q), 127.7 (q), 130.5 (C-2), 132.5 (q), 133.6 (C4), 136.2 (C-8), 139.8 (C-6), 168.1 (CO); MS (EI): 369 ( $\left.\mathrm{M}^{+}+1,22 \%\right), 368\left(\mathrm{M}^{+}, 100\right), 348\left(\mathrm{M}^{+}-\right.$ $\left.\mathrm{H}_{2} \mathrm{O}-2 \mathrm{H}, 10\right), 326\left(\mathrm{M}^{+}-\mathrm{Ac}+\mathrm{H}, 19\right), 325\left(\mathrm{M}^{+}-\mathrm{Ac}, 38\right), 305\left(\mathrm{M}^{+}-\mathrm{Ac}-\mathrm{H}_{2} \mathrm{O}-2 \mathrm{H}, 8\right), 283\left(\mathrm{M}^{+}-2 \mathrm{Ac}\right.$, 12), $282\left(\mathrm{M}^{+}-2 \mathrm{Ac}-\mathrm{H}, 11\right), 281\left(\mathrm{M}^{+}-2 \mathrm{Ac}-2 \mathrm{H}, 10\right), 268$ (8), 267 (14), 266 (13), 254 (14); Calculated for $\mathrm{C}_{24} \mathrm{H}_{20} \mathrm{~N}_{2} \mathrm{O}_{2}$ (\%): C 78.23, H 5.47, N 7.60; found C $77.96 \%$, H 5.73, N 7.71.

3,3'-Bis(benzoylamino)-1,1'-biazulene (9b). To the strongly stirred solution of the dimer 3a (52 mg, $0.1 \mathrm{mmol}$ ) in acetic acid $(3 \mathrm{~mL})$ at room temperature under inert atmosphere, a large excess of powdered zinc (350 mg) was added in small portions during 1 hour. The reduction was monitored by thin layer chromatography and when necessary, a supplementary amount of zinc had to be added. The color of the solution changed from brown to green. After dilution with DCM (5 mL) the solution was cooled at $0{ }^{\circ} \mathrm{C}$ and $20 \%$ aqueous sodium carbonate $(1 \mathrm{~mL})$ and benzoyl chloride in excess $(1 \mathrm{~mL})$ were added. The solution was stirred at $0{ }^{\circ} \mathrm{C}$ for $90 \mathrm{~min}$. After the dilution with DCM $(20 \mathrm{~mL})$ the mixture was washed with water, aqueous ammonia (20\%) and again with water. It is important to eliminate the excess of benzoyl chloride otherwise it hydrolyzes on the column chromatography with the $\mathrm{HCl}$ generation and completely destroy the product. The organic layer was dried $\left(\mathrm{Na}_{2} \mathrm{SO}_{4}\right)$ and the solvent vaporized in vacuum. The chromatography on alumina eluent DCM:triethylamine 9:1 afforded product $\mathbf{8 b}$ as the first colored fraction (18 mg, $37 \%$ yield). Green crystals, m. p. $175{ }^{\circ} \mathrm{C}$, ether, IR (KBr): $v_{\max } 710$ (s), 740 (m), 800 (m), 870 (m), 1033 (m), 1080 (m), 1130 (m), 1275 (m), 1368 (m), 1400 (m), 1518 (m), 1543 (m), 1570 (m), 1645 (s), 2970 (m), 3260 (s) cm ${ }^{-1}$; UV (MeOH): $\lambda_{\max }$ [nm] (log ع): 212 (4.47), 228 (4.54), 236 sh (4.53), 242 sh (4.53), 278 (4.53), 289 sh (4.52), 306 sh (4.52), 373 (4.03); ${ }^{1} \mathrm{H}$ NMR (DMSO-d d $_{6}$ : $\delta 7.09$ (t, $J=10.4 \mathrm{~Hz}, 2 \mathrm{H}, \mathrm{H}-5$ ), 7.11 (t, $J=9.6 \mathrm{~Hz}, 2 \mathrm{H}, \mathrm{H}-7$ ), 7.58 (t, $\left.J=6.4 \mathrm{~Hz}, 4 \mathrm{H}, \mathrm{H}-3^{\prime \prime}, \mathrm{H}-5^{\prime \prime}\right), 7.60$ (t, $\left.J=6.4 \mathrm{~Hz}, 2 \mathrm{H}, \mathrm{H}-4^{\prime \prime}\right), 7.64$ (t, $J=9.8 \mathrm{~Hz}, 2 \mathrm{H}, \mathrm{H}-$ 6), 8.11 (d, $J=6.6 \mathrm{~Hz}, 4 \mathrm{H}, \mathrm{H}-2^{\prime \prime}, \mathrm{H}-6^{\prime \prime}$ ), 8.30 (d, $J=9.6 \mathrm{~Hz}, 2 \mathrm{H}, \mathrm{H}-4$ ), 8.46 (s, $2 \mathrm{H}, \mathrm{H}-2$ ), 8.53(d, $J=10.0 \mathrm{~Hz}, 2 \mathrm{H}, \mathrm{H}-8), 10.62$ (s, $2 \mathrm{H}, \mathrm{NH}) ;{ }^{13} \mathrm{C}$ NMR (DMSO-d 6 ): $\delta 121.9$ (C-7), 122.8 (q), 123.1 (C-5), 125.6 (q), 127.8 (C-4"), 128.1 (C-3", C-5"), 128.6 (C-2", C-6"), 129.8 (q), 132.6 (C-2), 132.6 (C-8), 133.7 (q), 136.5 (C-4), 140.1 (C-6), 134.9 (q); MS (EI): 493 (M+1, $16 \%), 492\left(\mathrm{M}^{+}, 61\right), 472\left(\mathrm{M}^{+}-\mathrm{H}_{2} \mathrm{O}-2 \mathrm{H}, 18\right), 388\left(\mathrm{M}^{+}-\mathrm{Bz}+\mathrm{H}, 21\right), 387\left(\mathrm{M}^{+}-\mathrm{Bz}, 26\right), 367\left(\mathrm{M}^{+}-\mathrm{Bz}-\right.$ $\left.\mathrm{H}_{2} \mathrm{O}-2 \mathrm{H}, 18\right), 281$ (M+2-2Bz-H, 11), 266 (7), 265 (3), 264 (4), 254 (8), 253 (5), 252 (2), 247 (6), 
105 (Bz, 100), 77 (Ph, 69); Calculated for $\mathrm{C}_{34} \mathrm{H}_{24} \mathrm{~N}_{2} \mathrm{O}_{2}$ (\%): C 82.93, H 4.88, N 5.69; found $\mathrm{C}$ $82.88 \%, \mathrm{H} .4 .95$, N 5.65 .

3,3'-Bis(methoxycarbamide)-1,1'-biazulene (8). To the solution of the bis-amine $\mathbf{6}$, and anisidine, $7=\mathrm{H}$, cooled at $0{ }^{\circ} \mathrm{C}, 20 \%$ aqueous sodium carbonate $(1 \mathrm{~mL})$ was added followed by an excess of methyl chloroformate $(0.5 \mathrm{~mL})$. The reaction mixture was stirred for $90 \mathrm{~min}$ at $0{ }^{\circ} \mathrm{C}$ and the work-up was the same as for compound $\mathbf{9 b}$. The product collected as the first fraction represents probably a ureide because in the NMR spectrum methoxy group failed. The second green fraction represents the product 8 (12 mg, $30 \%$ yield), green crystals, m. p. $198{ }^{\circ} \mathrm{C}$ ether, IR (KBr): $v_{\max } 740(\mathrm{~m}), 1130(\mathrm{~m}), 1220(\mathrm{~m}), 1230(\mathrm{~m}), 1375$ (m), 1390 (m), 1570 (m), 1655 (s), 2920 (m), 3200-3300 cm ${ }^{-1}$; UV (MeOH): $\lambda_{\max }$ [nm] (log $\varepsilon$ ): 226 (4.36), 250 (4.41), 281 (4.60), 298 sh (4.52), 373 (4.03); ${ }^{1} \mathrm{H}$ NMR (DMSO-d 6 ): $\delta 4.46$ (s, $6 \mathrm{H}, \mathrm{CH}_{3}$ ), 7.04 (t, $J=10.0 \mathrm{~Hz}, 2 \mathrm{H}$, H-5), 7.12 (t, $J=9.6 \mathrm{~Hz}, 2 \mathrm{H}, \mathrm{H}-7$ ), 7.62 (t, $J=9.6 \mathrm{~Hz}, 2 \mathrm{H}, \mathrm{H}-6), 8.20$ (d, $J=10.0 \mathrm{~Hz}, 2 \mathrm{H}, \mathrm{H}-$ 4), 8.47 (s, $2 \mathrm{H}, \mathrm{H}-2$ ), 8.49 (d, $J=9.6 \mathrm{~Hz}, 2 \mathrm{H}, \mathrm{H}-8$ ), 10.67 (s, $2 \mathrm{H}, \mathrm{NH}$ ); ${ }^{13} \mathrm{C}-\mathrm{RMN}$ (DMSO-d ${ }_{6}$ ): $43.15\left(\mathrm{OCH}_{3}\right), 121.4$ (C-7), 122.7 (C-1,C-5), 124.8 (C-3), 128.0 (q), 130.3 (C-2), 132.7 (q), 133.4 (C-8), 136.3 (C-4), 139.9 (C-6), 164.4 (CO); Calculated for $\mathrm{C}_{24} \mathrm{H}_{20} \mathrm{~N}_{2} \mathrm{O}_{4}$ (\%): C 72.00, H 5.00, N 7.00; found C $72.16 \%$, H 5.13, N 7.01.

\section{Biazulene derivatives from the Schiff base dimer $5 a$}

1,1'-Biazulene-3,3'-dicarbaldehyde (11). To the solution of 5 a $(150 \mathrm{mg}, 0.288 \mathrm{mmol})$ in ethanol/water, $2 / 1 \mathrm{vol}(\mathrm{mL})$, copper acetate $(100 \mathrm{mg})$ was added and the mixture was vigorously refluxed for 24 hours. Water $(50 \mathrm{~mL})$ was added, the solution was acidified with $10 \% \mathrm{HCl}$ solution and the ethanol was vaporized in vacuum. The aqueous solution was extracted twice with DCM. The extract was washed with water, saturated $\mathrm{NaHCO}_{3}$ solution and again with water and some drops of triethylamine were added. After drying, the solution was filtered on thin alumina layer, DCM was vaporized in vacuum and the dialdehyde $\mathbf{1 1}$ was obtained as brown microcrystalline powder ( $175 \mathrm{mg}$, yield $100 \%$ ), mp $254-255{ }^{\circ} \mathrm{C}$ (lit. ${ }^{3 \mathrm{e}} 254-256{ }^{\circ} \mathrm{C}$ ).

1,1'-Biazulene (10). A. From the dimer $5 \mathbf{a}$. A solution of $\mathbf{5 a}(300 \mathrm{mg}, 0.576 \mathrm{mmol})$ and pyrrole (750 mg, $11.4 \mathrm{mmol})$ in acetic acid $(9 \mathrm{~mL}$ ) was stirred at room temperature under inert atmosphere for 7 days. The solvent was rotary-evaporated, and the residue was diluted with DCM. The organic solution was washed with $5 \%$ aqueous $\mathrm{NaHCO}_{3}$ and water. The organic layer was dried $\left(\mathrm{Na}_{2} \mathrm{SO}_{4}\right)$ and concentrated under reduced pressure. The chromatography of the residue on alumina with benzene afforded the product 10, (59 mg, yield $43 \%$ ). Using ethyl acetate as eluent, the second fraction can be obtained, representing a mixture of Schiff base 5a and aldehyde $\mathbf{1 1}$ in ratio 1.5/1 (14 mg mixture, conversion of $5 \mathbf{a} 95 \%$ ). The dimer $\mathbf{1 0}$ has the same characteristics as the product reported by Morita. ${ }^{9}$

B. From the bis-1,1'-azulene-3,3'-dicarbaldehyde (11). The dialdehyde 11 (100 mg, $0.322 \mathrm{mmol}$ ) and pyrrol (417 mg, $6.3 \mathrm{mmol})$ were dissolved in acetic acid (2 $\mathrm{mL})$ and DCM $(2 \mathrm{~mL}){ }^{9}$ After 3 days the starting material was completely transformed. After work-up, the residue was separated by chromatography on alumina The benzene eluted the dimer $\mathbf{1 0}$ (5 mg, 
yield $13 \%$ ), and DCM eluted 1,1'-biazulene-3-carbaldehyde, $17 \mathrm{R}=\mathrm{H}$ (5 mg, yield $11 \%$ ), which is characterized below.

3,3'-Dihidroxymethyl-1,1'-biazulene (12). The dialdehyde 11 (62 mg, 0.2 mmols) was reduced with an excess of $\mathrm{NaBH}_{4}$ in methanol $1 \mathrm{~h}$. After the usually work-up, the mixture was separated by chromatography on alumina and three fractions were collected: fraction 1 (16 mg), eluted with ethyl acetate $:$ n-pentane $=1: 2$ contains mainly the starting material and unidentified minor compounds (from the ${ }^{1} \mathrm{H}-\mathrm{NMR}$ spectrum), fraction 2 (4 mg) eluted with ethyl acetate contains unidentified compounds and fraction $3(18 \mathrm{mg})$ eluted with methanol represents the diol 12 (yield $30 \%$ ). The diol decomposes in time, however, its characterization was accomplished. The compound 12, green-black solid (dec. $210{ }^{0} \mathrm{C}$ ), IR (DCM): $v_{\max } 3400-3650 \mathrm{~cm}^{-1}(\mathrm{OH}) ;{ }^{1} \mathrm{H}-\mathrm{NMR}$ $\left(\mathrm{CDCl}_{3}\right): \delta 1.72$ (bs, $2 \mathrm{H}, 3 \mathrm{CH}_{2}-\mathrm{OH}$ ), 5.26 (s, $\left.4 \mathrm{H}, 3 \mathrm{CH}_{2}-\mathrm{OH}\right), 7.08$ (t, $J=10 \mathrm{~Hz}, 2 \mathrm{H}, \mathrm{H}-5$ ), 7.20 (t, $J=10 \mathrm{~Hz}, 2 \mathrm{H}, \mathrm{H}-7$ ), 7.61 (t, $J=10 \mathrm{~Hz}, 2 \mathrm{H}, \mathrm{H}-6$ ), 8.10 (s, $2 \mathrm{H}, \mathrm{H}-2$ ), 8.35 (d, $J=10 \mathrm{~Hz}$, $2 \mathrm{H}, \mathrm{H}-8), 8.53$ (d, $J=10 \mathrm{~Hz}, 2 \mathrm{H}, \mathrm{H}-4) ;{ }^{13} \mathrm{C}-\mathrm{NMR}\left(\mathrm{CDCl}_{3}\right): \delta 58.6\left(3-\mathrm{CH}_{2}\right), 123.0(\mathrm{C}-5), 123.4$ (C-7), 124.9 (q), 128.6 (q), 129.0 (q), 134.2 (C-8), 136.6 (C-4), 137.7 (q), 138.7 (C-6), 138.8 (C2); MS (EI): $316\left(\mathrm{M}^{+}+2,24 \%\right), 296\left(\mathrm{M}^{+}-\mathrm{H}_{2} \mathrm{O}, 44\right), 282\left(\mathrm{M}^{+}-\mathrm{H}-\mathrm{CH}_{2} \mathrm{OH}, 90\right), 265\left(\mathrm{M}^{+}-\mathrm{CH}_{2} \mathrm{OH}-\right.$ $\left.\mathrm{H}_{2} \mathrm{O}, 56\right), 252\left(\mathrm{M}^{+}-2 \mathrm{CH}_{2} \mathrm{OH}, 100\right), 126\left(\left(\mathrm{M}-2 \mathrm{CH}_{2} \mathrm{OH}\right)^{2+}, 40\right)$.

3,3'-Dimethyl-1,1'-biazulene (13). Dialdehyde 11 (45 mg, $0.16 \mathrm{mmols})$ was reduced with an excess of $\mathrm{NaBH}_{4}$ and $\mathrm{BF}_{3} \mathrm{Et}_{2} \mathrm{O}$ in diethyl ether-diglyme ${ }^{12}$ and the hydrocarbon 13 (20 mg, yield $50 \%$ ) was obtained as dark green crystals, mp $92-94{ }^{\circ} \mathrm{C} .{ }^{6 e}$ The ${ }^{1} \mathrm{H}-\mathrm{NMR}$ and MS spectra were identical with those described by Nozoe and colab. ${ }^{6 e} \mathrm{UV}$ (hexane): $\lambda_{\max }[\mathrm{nm}](\log \varepsilon) 226$ (4.22), 250 sh (4.31), 269 (4.58), 303 (4.31), 315 (4.37), 401 (3.971); ${ }^{13} \mathrm{C}-\mathrm{NMR}\left(\mathrm{CDCl}_{3}\right): \delta 12.7$ (3$\mathrm{CH}_{3}$ ), 121.1 (C-7), 121.9 (C-5), 124.9 (q), 125.6 (q), 133.8 (C-4), 135.8 (C-8), 136.6 (q), 137.6 (q), 138.1 (C-6), 139.4 (C-2).

1,1'-Biazulene-3,3'-dicarboxilic acid (14). Dialdehyde 11 (31 mg, $0.1 \mathrm{mmols})$ was oxidized ${ }^{13}$ with $\mathrm{KMnO}_{4}$ (31 mg, 0.19 mmols) in pyridine $(2.5 \mathrm{~mL}$ ) and after common work-up, 1,1'biazulene- 3,3'-dicarboxylic acid, 14, (15 mg, $44 \%$ ) were obtained, green-brown crystals, mp $290-292{ }^{\circ} \mathrm{C}$ (Lit. ${ }^{6 e} 290-293{ }^{\circ} \mathrm{C}$ ). ${ }^{1} \mathrm{H}-\mathrm{NMR}$ and MS spectra were identical with that reported. ${ }^{6 e}$

\section{Biazulene derivatives from the 1,1'-biazulene (10).}

Vilsmeier reaction. The Vilsmeier complex obtained from phosphoryl chloride (82 mg, $0.53 \mathrm{mmol})$ and DMF $(0.25 \mathrm{~mL})$ at $0{ }^{\circ} \mathrm{C}$ under inert atmosphere was added slowly to a solution of 10 (50 mg, $0.23 \mathrm{mmol}$ ) in DMF $(0.4 \mathrm{~mL})$ under stirring. After $30 \mathrm{~min}$ the mixture was quenched in ice and $2 \mathrm{M}$ aqueous $\mathrm{NaOH}$ was added until $\mathrm{pH}$ alkaline. After the extraction with DCM, the organic layer was washed with water, dried $\left(\mathrm{Na}_{2} \mathrm{SO}_{4}\right)$ and concentrated in vacuum. The residue was chromatographed on alumina with DCM and two fractions were collected: fraction 1, starting material, (4 mg, conversion $92 \%$ ) and fraction 2, 1,1'-biazulene-3carbaldehyde, $17 \mathrm{R}=\mathrm{H}$, (32 mg, $0.113 \mathrm{mmol}$, yield $63 \%$ ). With ethyl acetate eluted dialdehyde, 11 (15 mg, yield $27 \%$ ).

When an excess of Vilsmeier complex [from phosphoryl chloride (164 mg, $1.06 \mathrm{mmol}$ ) and DMF $(0.5 \mathrm{~mL})$ ] was added to the solution of $10(50 \mathrm{mg}, 0.23 \mathrm{mmol})$ in DMF $(0.4 \mathrm{~mL})$, after 30 min, only dialdehyde 11 resulted (conversion $100 \%$ and yield $70 \%$ ). 
1,1'-Biazulene-3-carbaldehyde, $17 \mathrm{R}=\mathrm{H}$, green-brown crystals, mp 65-67 ${ }^{\circ} \mathrm{C}$, IR (DCM): $v_{\max }$ 1140, 1450, 1585, 1655, $3060 \mathrm{~cm}^{-1}$; UV (dioxane): $\lambda_{\max }[\mathrm{nm}]$ (log $\varepsilon$ ): 240 (4.46), 267 (4.50), 296 (4.63), 321 (4.63), 588 (2.83); ${ }^{1} \mathrm{H}$ NMR $\left(\mathrm{CDCl}_{3}\right): \delta 7.11$ (t, $\left.J=10 \mathrm{~Hz}, 1 \mathrm{H}, \mathrm{H}-5^{\prime}\right), 7.22$ (t, $J=10$ Hz, 1 H, H-7'), 7.44 (t, $J=10 \mathrm{~Hz}, 1 \mathrm{H}, \mathrm{H}-7), 7.56$ (d, $\left.J=4 \mathrm{~Hz}, 1 \mathrm{H}, \mathrm{H}-3^{\prime}\right), 7.63$ (t, $J=10 \mathrm{~Hz}, 1$ H, H-6') 7.63 (t, $J=10$ Hz, 1 H, H-5), 7.86 (t, $J=10 \mathrm{~Hz}, 1 \mathrm{H}, \mathrm{H}-6), 8.09$ (d, $J=4 \mathrm{~Hz}, 1 \mathrm{H}, \mathrm{H}-$ 2'), 8.32 (d, $J=9.8 \mathrm{~Hz}, 1 \mathrm{H}, \mathrm{H}-4^{\prime}$ ), 8.43 (d, $J=9.8 \mathrm{~Hz}, 1 \mathrm{H}, \mathrm{H}-8^{\prime}$ ), 8.47 (s, $\left.1 \mathrm{H}, \mathrm{H}-2\right), 8.54$ (d, $J=$ $10 \mathrm{~Hz}, 1 \mathrm{H}, \mathrm{H}-8), 9.64$ (d, $J=10 \mathrm{~Hz}, 1 \mathrm{H}, \mathrm{H}-4), 10.49$ (s, $1 \mathrm{H}, \mathrm{CHO}) ;{ }^{13} \mathrm{C} \mathrm{NMR}\left(\mathrm{CDCl}_{3}\right): \delta$ 117.6 (C-3'), 123.3 (C-5'), 123.4 (C-7'), 124.7 (q), 125.1 (q), 127.8 (q),128.2 (C-7), 129.4 (C-6'), 135.8 (C-4'), 137.0 (q), 137.3 (C-8'), 137.6 (C-4), 138.3 (C-2'), 138.4 (C-5), 138.5 (C-8), 140.4 (C-6), 141.2 (q), 141.5 (q), 142.9 (C-2), 143.2 (q), 186.6 (CHO); MS (EI): $284\left(\mathrm{M}^{+}+2,2 \%\right), 283$ $\left(\mathrm{M}^{+}+1,22\right), 282\left(\mathrm{M}^{+}, 100\right), 281\left(\mathrm{M}^{+}-1,7\right), 253$ (25), 252 (70), 250 (26), 126 (49), 125 (26).

Friedel-Crafts acylation. A mixture of 10 (58 $\mathrm{mg}, 0.112 \mathrm{mmol}), \mathrm{SnCl}_{4}(0.4 \mathrm{~mL})$ and acetyl chloride in large excess $(20 \mathrm{~mL})$ was refluxed for $20 \mathrm{~min}$ in tetrachloromethane $(35 \mathrm{~mL})$. The reaction mixture was quenched in water $(600 \mathrm{~mL})$ and extracted with diethyl ether. The extract was washed with water, dried $\left(\mathrm{Na}_{2} \mathrm{SO}_{4}\right)$ and the solvent was vaporized in vacuum. The crude material was chromatographed on alumina (eluent, n-pentane:DCM, 1:1) and 3,3'-diacetyl-1,1'biazulene, $15 \mathrm{R}=\mathrm{CH}_{3}$ was collected as the colored fraction (22 mg, yield $58 \%$ ).

3,3'-Diacetyl-1,1'-biazulene (15). $\mathrm{R}=\mathrm{CH}_{3}$, green crystals, mp 248-250 ${ }^{\circ} \mathrm{C}$, IR (DCM): $v_{\max }$ 1160, 1190, 1220, 1360, 1450, 1640, 2995, $3070 \mathrm{~cm}^{-1}$; UV (dioxane): $\lambda_{\max }$ [nm] (log $\varepsilon$ ): 239 (4.52), 290 (4.75), 309 (4.68), 392 (4.13), 581 (2.81); ${ }^{1} \mathrm{H} \mathrm{NMR}\left(\mathrm{CDCl}_{3}\right): \delta 2.78$ (s, $\left.6 \mathrm{H}, \mathrm{CH}_{3}\right)$, 7.41 (t, $J=9.8 \mathrm{~Hz}, 2 \mathrm{H}, \mathrm{H}-7), 7.66$ (t, $J=9.8 \mathrm{~Hz}, 2 \mathrm{H}, \mathrm{H}-5), 7.86$ (t, $J=9.8 \mathrm{~Hz}, 2 \mathrm{H}, \mathrm{H}-6), 8.36$ (d, $J=9.8 \mathrm{~Hz}, 2 \mathrm{H}, \mathrm{H}-8), 8.44$ (s, $2 \mathrm{H}, \mathrm{H}-2), 9.98$ (d, $J=9.8 \mathrm{~Hz}, 2 \mathrm{H}, \mathrm{H}-4) ;{ }^{13} \mathrm{C} \mathrm{NMR}\left(\mathrm{CDCl}_{3}\right): \delta$ $29.3\left(\mathrm{CH}_{3}\right), 124.2$ (q), 124.7 (q), 127.5 (C-7), 129.6 (C-5), 137.6 (C-4), 140.0 (C-8), 140.3 (C-6), 140.7 (q), 141.8 (C-2), 142.3 (q), 195.5 (CHO); MS (EI): $340\left(\mathrm{M}^{+}+2,4 \%\right), 339\left(\mathrm{M}^{+}+1,23\right), 338$ $\left(\mathrm{M}^{+}, 100\right), 323\left(\mathrm{M}^{+}-\mathrm{CH}_{3}, 58\right), 252\left(\mathrm{M}^{+}-2 \mathrm{COCH}_{3}, 62\right), 250$ (37), 154 (50), 125 (35).

Coupling reaction with diazonium salts. A solution of 4-nitrophenildiazonium chloride, prepared at $0{ }^{\circ} \mathrm{C}$ from 4-nitroaniline (100 mg, $\left.0.72 \mathrm{mmol}\right), 37 \%$ aqueous $\mathrm{HCl}(3 \mathrm{~mL})$ and sodium nitrite $(50 \mathrm{mg}, 0.72 \mathrm{mmol})$ in water $(2 \mathrm{~mL})$, was added slowly to a stirred solution of 1,1'-biazulene (75 mg, $0.29 \mathrm{mmol})$ and sodium acetate $(230 \mathrm{mg})$ in ethanol $(20 \mathrm{~mL})$. After stirring at $0{ }^{\circ} \mathrm{C}$ for $30 \mathrm{~min}$ and then at room temperature for $3 \mathrm{~h}$ and work-up, the crude material was separated on silica with benzene resulting fraction 1 , unreacted biazulene (5 mg, conversion $93 \%$ ); fraction 2, the product 3-(4"'-nitrophenylazo)-1,1'-biazulene, $16 \mathbf{b}$ (20 mg, yield 18\%) (the disubstituted product failed).

3-(4-Nitrophenylazo)-1,1'-biazulene (16b). brown needles, mp 170-171 ${ }^{\circ} \mathrm{C}$ IR (DCM): $v_{\max }$ 1110, 1150, 1190, 1340, 1520, $1580 \mathrm{~cm}^{-1}$; UV (dioxane): $\lambda_{\max }$ [nm] (log $\left.\varepsilon\right): 242$ (4.50), 272 (4.49), 294 (4.48), 306 (4.47), 403 (4.35), 513 (4.18); ${ }^{1} \mathrm{H}$ NMR $\left(\mathrm{CDCl}_{3}\right): \delta 7.17$ (t, $J=10 \mathrm{~Hz}, 1$ H, H-5') 7.24 (t, $\left.J=10 \mathrm{~Hz}, 1 \mathrm{H},{\mathrm{H}-7^{\prime}}^{\prime}\right), 7.37$ (t, $\left.J=10 \mathrm{~Hz}, 1 \mathrm{H}, \mathrm{H}-7\right), 7.56$ (d, J = $4 \mathrm{~Hz}, 1 \mathrm{H}, \mathrm{H}-$ 3'), 7.58 (t, $J=10 \mathrm{~Hz}, 1 \mathrm{H}, \mathrm{H}-5), 7.65$ (t, $\left.J=10 \mathrm{~Hz}, 1 \mathrm{H}, \mathrm{H}-6^{\prime}\right), 7.83$ (t, $J=9.6 \mathrm{~Hz}, 1 \mathrm{H}, \mathrm{H}-6$ ), 
8.08 (dd, $J=8.8,2$ Hz, 2 H, H-3", H-5'), 8.12 (d, $J=4$ Hz, $1 \mathrm{H}, \mathrm{H}-2^{\prime}$ ), 8.37 (dd, $J=9.2,2 \mathrm{~Hz}, 2$ H, H-2" , H-6"'), 8.42-8.48 (m, 4 H, H-2, H-4', H-8, H-8'), 9.43 (d, J = 3.6 Hz, 1 H, H-4); MS (EI): $404\left(\mathrm{M}^{+}+1,17 \%\right), 403\left(\mathrm{M}^{+}, 66\right), 402\left(\mathrm{M}^{+}-1,55\right), 373$ (24), 372 (23), 269 (29), 253 (40), 252 (100), 250 (45).

\section{Acknowledgements}

The material supporting came from the Ministry of Education and Research, Bucharest as the CERES Program.

\section{References and Notes}

1. Zeller, K. P. In Methoden der Organischen Chemie (Houben Weyl), B. V/2c, Georg Thieme: Verlag, Stuttgart, New York, 1985.

2. (a) Iftime, G.; Lacroix, P. G.; Nakatani, K.; Razus, A. C. Tetrahedron Lett. 1998, 39, 6853.

(b) Lacroix, P. G.; Malfant, I.; Iftime, G.; Razus, A. C.; Nakatani K.; Delaire, J. A. Chem. Eur. J. 2000, 6, 2599.

3. (a) Razus, A. C.; Birzan, L.; Razus, S. A.; Horga, V. Rev. Roum. Chim. 1999, 44, 235. (b) Razus, A. C. J. Chem. Soc., Perkin Trans. 1 2000, 981. (c) Razus, A. C.; Nitu, C. J. Chem. Soc., Perkin Trans. 1 2000, 989. (d) Totir, N. D.; Razus, A. C.; Nitu, C.; Lete, C.; Lupu, S. $189^{\text {th }}$ Meeting of the Electrochemical Society, Phoenix Arizona, October 2000. (e) Razus, A. C.; Nitu, C.; Carvaci, S.; Birzan, L.; Razus, S. A.; Pop, M.; Tarko, L. J. Chem. Soc., Prekin Trans. 1 2001, 1227.

4. The researches on the oxidation of the compounds1c are in progress.

5. (a) Kurihara, T.; Suzuki, T.; Wakabayashi, H.; Ishikawa, S.; Shindo, K.; Shimada, Y.; Chiba, H.; Miyashi, T.; Yasunami, M.; Nozoe, T. Bull. Chem Soc. Jpn. 1996, 69, 2003. (b) Nozoe, T.; Takeshita, H. ibid. 1996, 69, 1149.

6. (a) Bindl, J.; Philidis, G.; Daub, J. Angew. Chem. 1984, 96, 294. (b) Briquet, A. A. S.; Hansen, H. -J. Helv. Chim. Acta 1994, 77, 1577. (c) Pailer, M.; Lobenwein, H. Monatsh. Chem. 1971, 102, 1558. (d) Matsubara, Y.; Takekuma, S.; Yokoi, K.; Yamamoto, H.; Nozoe, T. Bull. Chem. Soc. Jpn. 1987, 60, 1415. (e) Takekuma, S.; Matsubara, Y.; Yamamoto, H.; Nozoe, T. ibid. 1987, 60, 3721. (f) Takekuma, S.; Matsubara, Y.; Yamamoto, H.; Nozoe, T. ibid. 1988, 61, 475. (g) Matsubara, Y.; Morita, M.; Takekuma, S.; Nakano, T.; Yamamoto, H.; Nozoe, T. ibid. 1991, 64, 3497. (h) Gerson, F.; Scholz, M.; Hansen, H. -J.; Uebelhardt, P. J. Chem. Soc., Perkin Trans. 2 1995, 215.

7. Waltman, R. J.; Bargon, J. Can. J. Chem. 1986, 64, 76.

8. Morita, T.; Takase, K. Bull. Chem. Soc. Jpn. 1982, 55, 1144.

9. Ito, S.; Morita, N.; Asao, T. Bull. Chem. Soc. Jpn. 1999, 72, 2543. 
10. Anderson, A. G.; Scotoni, R.; Cowels, E. J.; Fritz, C. G. J. Chem. Soc. 1957, 22, 1193.

11. Hafner, K.; Bernhardt, C. Liebigs Ann. Chem. 1959, 625, 108.

12. Anderson, A. G.; Breazeale, R. D. J. Org. Chem. 1969, 34, 2375.

13. Treibs, W.; Vollrad, Ch.; Reimann, M. Liebigs Ann. Chem. 1961, 648, 174. 